Acta Haematol 2016;135:211-216

DOI: $10.1159 / 000443469$
Received: August 24, 2015

Accepted after revision: December 15, 2015

Published online: February 26, 2016

\title{
Haploidentical Donors: Can Faster Transplantation Be Life-Saving for Patients with Advanced Disease?
}

\author{
Alina Tanase $^{a}$ Ciprian Tomuleasa $^{\mathrm{b}} \quad$ Alexandra Marculescu $^{\mathrm{a}} \quad$ Alexandru Bardas $^{\mathrm{a}}$ \\ Anca Colita $^{a}$ Carmen Orban $^{a}$ Stefan Octavian Ciurea ${ }^{c}$ \\ ${ }^{a}$ Department of Stem Cell Transplantation, Fundeni Clinical Institute, Bucharest, and b Department of Hematology, \\ Ion Chiricuta Oncology Institute, and Iuliu Hatieganu University of Medicine and Pharmacy, Cluj Napoca, Romania; \\ 'Division of Cancer Medicine, Department of Stem Cell Transplantation, The University of Texas MD Anderson \\ Cancer Center, Houston, Tex., USA
}

\section{Key Words}

Haploidentical stem cell transplantation · Hodgkin

lymphoma $\cdot$ Posttransplantation cyclophosphamide

\begin{abstract}
Haploidentical stem cell transplantation is a therapeutic option for patients without an HLA-matched donor. It is increasingly being used worldwide due to the application of posttransplantation cyclophosphamide and is associated with lower incidence of graft-versus-host disease and treatmentrelated mortality. Haploidentical donors are generally available for most patients and stem cells can be rapidly obtained. Delays in transplantation while waiting for unrelated donor cells can be potentially problematic for patients with advanced disease at risk for progression; thus, the use of haploidentical donors, especially in this setting, can be life-saving. Here we reviewed the literature on haploidentical stem cell transplantation performed with posttransplantation cyclophosphamide.

(c) 2016 S. Karger AG, Basel
\end{abstract}

\section{Introduction}

Hematopoietic stem cell transplantation is an effective treatment for advanced hematological malignancies. An HLA-identical related donor is preferred; however, such donors are unavailable for the majority of patients (70\%) $[1,2]$. The traditional alternative donor has been a matched unrelated donor. However, acquisition of unrelated donor cells is limited by significant expenses and delays which are on average approximately 4 months [3, 4]. Such a delay in performing an unrelated donor transplant could mean that a proportion of patients with advanced disease may progress while awaiting transplantation. Haploidentical hematopoietic stem cell transplantation (haploSCT) is increasingly being performed worldwide. Mismatched relatives represent an alternative source of readily available progenitor cells for virtually all patients $[5,6]$. Historically, haploidentical stem cell transplantation has been limited by high rates of graft rejection and acute graft-versus-host disease (GVHD) elicited by the presence of donor $\mathrm{T}$ cells in the haploidentical graft, while a strong antitumor effect was observed [7]. The use

\section{KARGER}

E-Mail karger@karger.com

www.karger.com/aha (c) 2016 S. Karger AG, Basel

0001-5792/16/1354-0211\$39.50/0
Ciprian Tomuleasa, $\mathrm{MD}, \mathrm{PhD}$

Department of Hematology, Ion Chiricuta Oncology Institute Bulevardul 21 Decembrie 1918 Nr. 73 RO-400124 Cluj Napoca (Romania)

E-Mail ciprian.tomuleasa@umfcluj.ro 
of a T-cell-depleted graft from mismatched relatives decreased the rate of GVHD at the expense of a higher risk of rejection and reduced graft-versus-leukemia effect with an increased relapse rate and severe infections [8]. Two main alternative approaches to complete T-cell depletion have been developed - the use of a T-cell-replete graft followed by posttransplantation cyclophosphamide (PTCy), tacrolimus and mycophenolate for GVHD prophylaxis, and partial T-cell depletion (e.g. depletion of $\alpha \beta$ T cells from the graft) $[9,10]$. PTCy is gaining widespread acceptance due to the low cost of the drugs, lack of sophisticated devices to manipulate the graft and rapid applicability. Transplant outcomes using haploidentical donors with PTCy have improved over the past several years and are comparable with outcomes of matched unrelated donors [11-13]. These encouraging early results will likely extend this form of transplantation worldwide. Here we review the literature on this topic, probably the most important development in transplantation at present, and report the first successful application of this type of transplant in Romania.

\section{PTCy for GVHD Prevention}

Over the last few years, haploidentical donors have become a viable source of stem cells in transplant hematology due to a better understanding of the HLA barriers, control of alloreactivity and improvements in immunological reconstitution. These have been primarily accomplished by the use of PTCy as the main method of GVHD prevention in patients treated with a T-cell-replete graft [14]. In a seminal paper published by Berenbaum and Brown [15] in 1963, the first investigation of the effects of cyclophosphamide on the immune system was presented. This group injected $200 \mathrm{mg} / \mathrm{kg}$ cyclophosphamide in the peritoneum of mice, which had also received a major histocompatibility mismatched skin graft. The transplanted mice treated with cyclophosphamide 3 or 4 days after the skin graft exhibited a delayed graft rejection. This proved that PTCy exerted a favorable effect on graft survival, correlating with a time-dependent immune suppression. Three years later, Santos and Owens [9] applied this hypothesis in stem cell transplantation at the Johns Hopkins Medical Institutions (JHMI) and showed that rats treated with PTCy 2 days after transplant had a much lower incidence of skin GVHD. The preclinical data on mice and PTCy were also confirmed by Mayumi et al. [16], who proved that tolerogen, antimitotic drugs and their doses, timing, route of administration, combined immunosup- pressants, and supportive treatment were all crucial for successful induction of a long-lasting skin tolerance. Luznik et al. [17] subsequently showed that major histocompatibility-mismatched bone marrow cells have the ability to engraft donor cells following nonmyeloablative conditioning chemotherapy consisting of fludarabine or cyclophosphamide, plus total body irradiation, and use of PTCy on day +3 . These results were strengthened by an improvement in survival of mice that received PTCy.

After the administration of cyclophosphamide, the alloantigen-stimulated $\mathrm{T}$ lymphocytes are directly effected first, with both antihost $\mathrm{T}$ cells and recipient antidonor $\mathrm{T}$ cells undergoing apoptosis after a few days [18]. Alloreactive $\mathrm{T}$ lymphocytes have the ability to proliferate extensively in the immediate posttransplant period because of the major HLA mismatch. Still, donor stem cells and memory $\mathrm{T}$ lymphocytes are spared, owing to their quiescent nature and lack of susceptibility to cytotoxic chemotherapy which eliminates predominantly differentiated cells. Persistence of stem cells would reconstitute donor hematopoiesis, and memory T cells likely help the defense against posttransplant infections, as seen in figure 1 . An improvement in immunological reconstitution and a lower incidence of infectious complications was first assessed by the physicians at The University of Texas MD Anderson Cancer Center (MDACC) [19]. This group treated a similar number of patients with a T-cell-replete haploSCT with complete T-cell depletion with CD34+ selection, and showed significantly improved outcomes of patients treated with PTCy. This has made the change from complete T-cell depletion to partial depletion of alloreactive T cells with PTCy, offering the clinical proof for the improved efficacy with this approach. The issue of immunological reconstitution was also investigated at the San Raffaele Scientific Institute in Milano a few months ago, concluding that at the antigen-specific and clonal level, memory stem $T$ cells can differentiate directly from naïve precursors infused within the graft and that the extent of their generation might correlate with interleukin 7 serum levels [20]. In the same issue of Blood, another group from Milan transplant immunology group described their experience and affirmed that donor-naïve $\mathrm{T}$ cells specific for exogenous and tumor antigens persist in the host and contribute to peripheral reconstitution by differentiating into effectors. In a similar manner, pathogen-specific memory $\mathrm{T}$ cells generate detectable recall responses, but only in the presence of the cognate antigen [21]. Another mechanism by which PTCy is associated with a drug-induced tolerance is the decrease in the number of antihost $\mathrm{T}$ cells derived from the hematopoietic 
Fig. 1. Mechanism of action of PTCy.

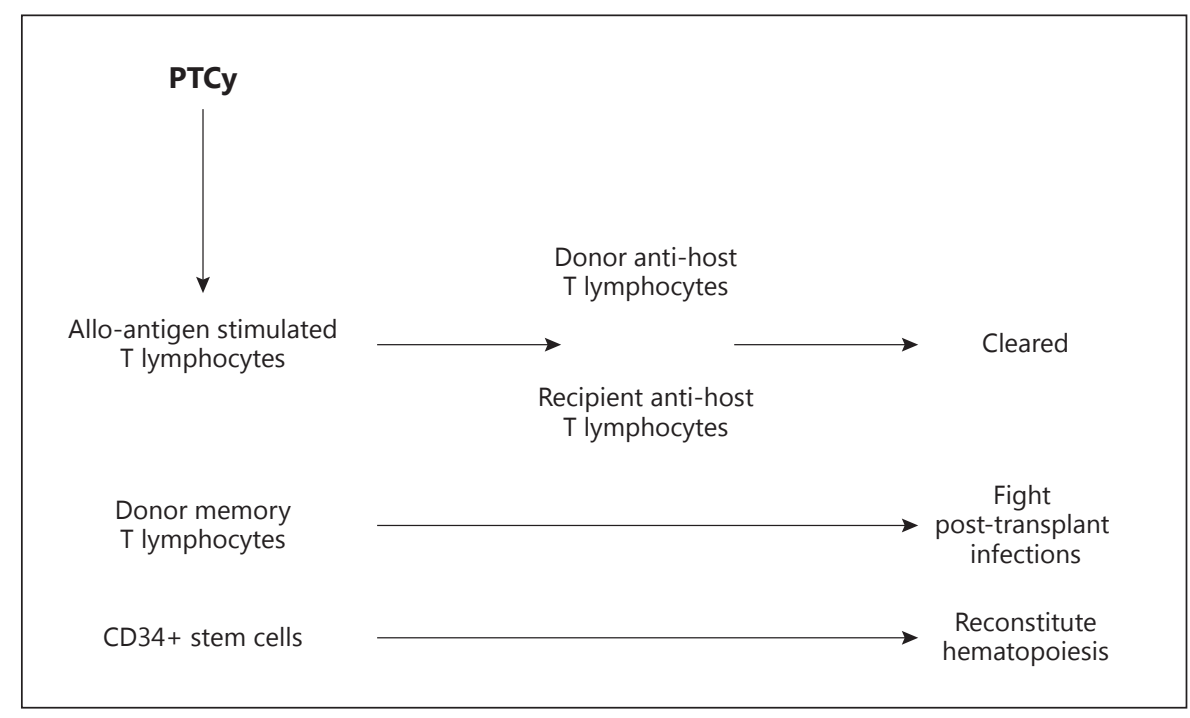

stem cells of the thymus [16]. A possible explanation for this differential effect of cyclophosphamide on various cells present in an unmanipulated graft may reside in the fact that hematopoietic stem cells are nondividing cells that express a high level of aldehyde dehydrogenase, an enzyme that allows the cell to be resistant to various drugs, including cyclophosphamide [22-25]. Other cells, such as NK cells and naïve T and B lymphocytes, are more sensitive to cyclophosphamide due to the low levels of the enzyme and are rapidly eliminated [26].

An important technical aspect for treatment of haploSCT patients is the conditioning regimen used in preparation for transplantation which was recently reviewed [11]. Initially, a nonmyeloablative conditioning regimen was used [27] consisting of the administration of $30 \mathrm{mg} / \mathrm{m}^{2}$ fludarabine on days -6 to -2 , total body irradiation of $2 \mathrm{~Gy}$ on day -1 , and $50 \mathrm{mg} / \mathrm{kg}$ PTCy on day +3 . Subsequently, cyclophosphamide was added with fludarabine and another dose of PTCy was also added on day +4 as it was appreciated that patients who received 2 doses had better control of GVHD [28-32]. Comparative outcomes with umbilical cord blood transplantation (UCBT) have been reported with this regimen [33]. While no significant differences were noted in overall survival, remarkably low nonrelapse mortality (NRM) (7\%) and no grade III-IV acute GVHD were observed in patients treated with a haploidentical donor. While the NRM was much better in the haploSCT group (7\% for haploSCT vs. $24 \%$ for UCBT), the relapse rate appeared higher for haploidentical transplants (45\% for haploSCT vs. $31 \%$ for UCBT).

Haploidentical Transplantation with PTCy
For this reason, the MDACC group has used a more intense, melphalan-based conditioning regimen for haploidentical stem cell transplantation with PTCy. Melphalan is an alkylating agent with broad antitumor effects including for myeloid and lymphoid diseases [34]. A modified fludarabine-melphalan-based conditioning regimen has been used successfully for these patients, which was initially reported for patients treated with Tcell depletion [29]. This conditioning chemotherapy regimen allowed a high engraftment rate with low NRM and better disease control in patients with acute leukemia and lymphoma $[35,36]$. This remarkable American experience was not without consequences in transplant hematology worldwide: the number of haploidentical transplants reported to the CIBMTR database have doubled since 2010 and increased by $96 \%$ in Europe in the last 4 years, as reported by the European Group for Blood and Marrow Transplantation (EBMT) [37].

A major concern in using PTCy has been increased posttransplant immune suppression and delayed immunological reconstitution $[38,39]$. However, in a recent report from the MDACC group, the kinetics of lymphocyte reconstitution both in HLA-matched transplants performed with conventional GVHD prevention and haploidentical transplants performed with PTCy showed a remarkably similar pattern of immunological reconstitution [37]. CD4+ and CD8+ lymphocytes, naïve and memory T cells, NK cells, and B lymphocytes were evaluated at 1,2, 3, 6, and 12 months after the transplant and showed almost identical patterns, except that matched siblings tended to have higher numbers of $\mathrm{CD} 4+$ and 
CD8 $+\mathrm{T}$ cells on day +30 posttransplant, which may explain, at least in part, a lower NRM associated with HLAmatched sibling donors. These results suggest that PTCy does not significantly affect the immune reconstitution after haploidentical transplantation, which was also confirmed by Wang et al. [38]. Employing both syngeneic and allogeneic minor antigen-mismatched T-cell-replete models of transplantation, Ross et al. [40] showed that PTCy abrogates GVHD and preserves most cells that are dividing because of the accompanying lymphopenia after exposure. These results are in accordance with the data of Ganguly et al. [41], which state that PTCy-mediated protection against GVHD is not singularly dependent on depletion of donor alloreactive $\mathrm{T}$ cells but also requires rapidly recovering donor Tregs to initiate and maintain alloimmune regulation.

\section{Conclusion}

Finding a suitable donor is the main challenge for allogeneic stem cell transplantation. For up to $50 \%$ of all potential transplant patients, an HLA-matched sibling donor or an HLA-matched unrelated donor cannot be identified or cannot be identified in time, and the patient often relapses and dies from disease progression. Partially HLA-matched related donors, also known as an HLAhaploidentical first-degree relative, which are available for most patients, fill an important need for transplantation.

However, until recently this procedure has been fraught by severe toxicity and treatment-related mortality - initially by a high incidence of hyperacute GVHD [42], and more recently by high NRM associated with extensive T-cell depletion [43]. A major breakthrough was the development of PTCy, which has allowed the use of a
non-T-cell-depleted graft with effective control of GVHD and a lower incidence of infectious complications. PTCy has now been shown to be effective with a variety of preparative regimens with very good results confirmed by several groups and rapid expansion worldwide. The use of haploidentical donors as compared to unrelated donors, including cord blood, is even more important in Eastern European countries such as Romania as well as in other developing countries that do not have public cord blood banks due to the high costs associated with maintaining these banks. Such countries have difficulty obtaining unrelated donor cells due to the high costs associated with acquisition of these products. In addition, a longer time for unrelated donor search, donor ineligibility and longer time to transplantation in general associated with unrelated donor transplantation are important limitations, as seen in this case.

In conclusion, haploidentical stem cell transplantation is emerging as a fast type of transplant irrespective of the race of the recipient, offering a therapeutic alternative for a wide variety of hematological malignancies and thus extending transplantation to patients who, until now, have not had access to this life-saving procedure.

\section{Acknowledgements}

The current paper is supported by the international grant Romania-European Economical Space (Norway) 2015-2016 ('Innovative Nanoparticles-Based Chemotherapy for Acute Myeloid Leukemia' - Nano-Chemotherapy) awarded to Alina Tanase and Ciprian Tomuleasa.

\section{Disclosure Statement}

The authors declare no potential conflict of interest.

\section{References}

1 Horowitz MM: Does matched unrelated donor transplantation have the same outcome as matched sibling transplantation in unselected patients? Best Pract Res Clin Haematol 2012; 25:483-486.

2 Gupta V, Tallman MS, Weisdorf DJ: Allogeneic hematopoietic cell transplantation for adults with acute myeloid leukemia: myths, controversies, and unknowns. Blood 2011; 117:2307-2318
3 Kekre N, Antin JH: Hematopoietic stem cell transplantation donor sources in the 21st century: choosing the ideal donor when a perfect match does not exist. Blood 2014;124:334343.

4 Eapen M, O'Donnell P, Brunstein CG, Wu J, Barowski K, Mendizabal A, Fuchs EJ: Mismatched related and unrelated donors for allogeneic hematopoietic cell transplantation for adults with hematologic malignancies. Biol Blood Marrow Transplant 2014;20: 1485-1492.
5 Ballen KK, Koreth J, Chen YB, Dey BR, Spitzer TR: Selection of optimal alternative graft source: mismatched unrelated donor, umbilical cord blood, or haploidentical transplant. Blood 2012;119:1972-1980.

6 Bacigalupo A: Matched and mismatched unrelated donor transplantation: is the outcome the same as for matched sibling donor transplantation? Hematology Am Soc Hematol Educ Program 2012;2012:223-229. 
7 Kay HE, Watson JG, Jameson B, Morgenstern GR, Powles RL: Infections after bone marrow transplantation using cyclosporine. Transplantation 1983;36:491-495.

8 Marmont AM, Horowitz MM, Gale RP, Sobocinski K, Ash RC, van Bekkum DW, Champlin RE, Dicke KA, Goldman JM, Good RA: T-cell depletion of HLA-identical transplants in leukemia. Blood 1991;78:2120-2130.

9 Santos GW, Owens AH: Production of graftversus-host disease in the rat and its treatment with cytotoxic agents. Nature 1966;210:139140.

10 Mixter PF, Sydora BC, Hershberg RM, Kronenberg M: Depletion of mouse alpha beta $\mathrm{T}$ cell antigen receptor bearing lymphocytes by neonatal monoclonal antibody treatment. J Immunol 1991;147:4109-4117.

11 Shabbir-Moosajee M, Lombardi L, Ciurea SO: An overview of conditioning regimens for haploidentical stem cell transplantation with post-transplantation cyclophosphamide. Am J Hematol 2015;90:541-548.

12 Di Stasi A, Milton DR, Poon LM, Hamdi A, Rondon G, Chen J, Pingali SR, Konopleva M, Kongtim P, Alousi A, Qazilbash MH, Ahmed S, Bashir Q, Al-atrash G, Oran B, Hosing CM, Kebriaei P, Popat U, Shpall EJ, Lee DA, de Lima M, Rezvani K, Khouri IF, Champlin RE, Ciurea SO: Similar transplantation outcomes for acute myeloid leukemia and myelodysplastic syndrome patients with haploidentical versus 10/10 human leukocyte antigenmatched unrelated and related donors. Biol Blood Marrow Transplant 2014;20:19751981.

13 Ciurea SO, Bayraktar UD: 'No donor'? Consider a haploidentical transplant. Blood Rev 2015;29:63-70.

14 Ciurea SO, Mulanovich V, Saliba RM, Bayrak$\operatorname{tar}$ UD, Jiang Y, Bassett R, Wang SA, Konopleva M, Fernandez-Vina M, Montes N, Bosque D, Chen J, Rondon G, Alatrash G, Alousi A, Bashir Q, Korbling M, Qazilbash M, Parmar S, Shpall E, Nieto Y, Hosing C, Kebriaei P, Khouri I, Popat U, de Lima M, Champlin RE: Improved early outcomes using a $T$ cell replete graft compared with $T$ cell depleted haploidentical hematopoietic stem cell transplantation. Biol Blood Marrow Transplant 2012;18:1835-1844.

15 Berenbaum MC, Brown IN: Prolongation of homograft survival in mice with single doses of cyclophosphamide. Nature 1963;200:84.

16 Mayumi H, Umesue M, Nomoto K: Cyclophosphamide-induced immunological tolerance: an overview. Immunobiology 1996;195: 129-139.

17 Luznik L, Jalla S, Engstrom LW, Iannone R, Fuchs EJ: Durable engraftment of major histocompatibility complex-incompatible cells after nonmyeloablative conditioning with fludarabine, low-dose total body irradiation, and posttransplantation cyclophosphamide. Blood 2001;98:3456-3464.
18 Luznik L, O’Donnell PV, Fuchs EJ: Posttransplantation cyclophosphamide for tolerance induction in HLA-haploidentical bone marrow transplantation. Semin Oncol 2012; 39:683-693.

19 Ciurea SO, Mulanovich V, Saliba RM, Bayraktar UD, Jiang Y, Bassett R, Wang SA, Konopleva M, Fernandez-Vina M, Montes N, Bosque D, Chen J, Rondon G, Alatrash G, Alousi A, Bashir Q, Korbling M, Qazilbash M, Parmar S, Shpall E, Nieto Y, Hosing C, Kebriaei P, Khouri I, Popat U, de Lima M, Champlin RE: Improved early outcomes using a T cell replete graft compared with $\mathrm{T}$ cell depleted haploidentical hematopoietic stem cell transplantation. Biol Blood Marrow Transplant 2012;18:1835-1844.

20 Cieri N, Oliveira G, Greco R, Forcato M, Taccioli C, Cianciotti B, Valtolina V, Noviello M, Vago L, Bondanza A, Lunghi F, Marktel S, Bellio L, Bordignon C, Bicciato S, Peccatori J, Ciceri F, Bonini C: Generation of human memory stem $\mathrm{T}$ cells after haploidentical $\mathrm{T}$ replete hematopoietic stem cell transplantation. Blood 2015;125:2865-2874.

21 Roberto A, Castagna L, Zanon V, Bramanti S, Crocchiolo R, McLaren JE, Gandolfi S, Tentorio P, Sarina B, Timofeeva I, Santoro A, Carlo-Stella C, Bruno B, Carniti C, Corradini P, Gostick E, Ladell K, Price DA, Roederer M, Mavilio D, Lugli E: Role of naive-derived T memory stem cells in T-cell reconstitution following allogeneic transplantation. Blood 2015; 125:2855-2864.

22 Hoang VT, Buss EC, Wang W, Hoffmann I, Raffel S, Zepeda-Moreno A, Baran N, Wuchter P, Eckstein V, Trumpp A, Jauch A, Ho AD, Lutz C: The rarity of ALDH(+) cells is the key to separation of normal versus leukemia stem cells by ALDH activity in AML patients. Int J Cancer 2015;137:525-536.

23 Smith C, Gasparetto M, Humphries K, Pollyea DA, Vasiliou V, Jordan CT: Aldehyde dehydrogenases in acute myeloid leukemia. Ann NY Acad Sci 2014;1310:58-68.

24 Schuurhuis GJ, Meel MH, Wouters F, Min LA, Terwijn M, de Jonge NA, Kelder A, Snel AN, Zweegman S, Ossenkoppele GJ, Smit L: Normal hematopoietic stem cells within the AML bone marrow have a distinct and higher ALDH activity level than co-existing leukemic stem cells. PLoS One 2013;8:e78897.

25 Buss EC, Ho AD: Leukemia stem cells. Int J Cancer 2011;129:2328-2336.

26 Jones RJ, Barber JP, Vala MS, Collector MI, Kaufmann SH, Ludeman SM, Colvin OM, Hilton J: Assessment of aldehyde dehydrogenase in viable cells. Blood 1995;85:2742-2746.

27 O’Donnell PV, Luznik L, Jones RJ, Vogelsang GB, Leffell MS, Phelps M, Rhubart P, Cowan K, Piantados S, Fuchs EJ: Nonmyeloablative bone marrow transplantation from partially HLA-mismatched related donors using posttransplantation cyclophosphamide. Biol Blood Marrow Transplant 2002;8:377-386.
28 Luznik L, Engstrom LW, Iannone R, Fuchs EJ: Posttransplantation cyclophosphamide facilitates engraftment of major histocompatibility complex-identical allogeneic marrow in mice conditioned with low-dose total body irradiation. Biol Blood Marrow Transplant 2002;8:131-138.

29 Tomuleasa C, Fuji S, Cucuianu A, Kapp M, Pileczki V, Petrushev B, Selicean S, Tanase A, Dima D, Berindan-Neagoe I, Irimie A, Einsele $\mathrm{H}$ : MicroRNAs as biomarkers for graft-versus-host disease following allogeneic stem cell transplantation. Ann Hematol 2015;94:10811092.

30 Raiola AM, Dominietto A, di Grazia C, Lamparelli T, Gualandi F, Ibatici A, Bregante S, Van Lint MT, Varaldo R, Ghiso A, Gobbi M, Carella AM, Signori A, Galaverna F, Bacigalupo A: Unmanipulated haploidentical transplants compared with other alternative donors and matched sibling grafts. Biol Blood Marrow Transplant 2014;20:1573-1579.

31 Castagna L, Crocchiolo R, Furst S, Bramanti S, El Cheikh J, Sarina B, Granata A, Mauro E, Faucher C, Mohty B, Harbi S, Chabannon C, Carlo-Stella C, Santoro A, Blaise D: Bone marrow compared with peripheral blood stem cells for haploidentical transplantation with a nonmyeloablative conditioning regimen and post-transplantation cyclophosphamide. Biol Blood Marrow Transplant 2014; 20:724-729.

32 Burroughs LM, O’Donnell PV, Sandmaier BM, Storer BE, Luznik L, Symons HJ, Jones RJ, Ambinder RF, Maris MB, Blume KG, Niederwieser DW, Bruno B, Maziarz RT, Pulsipher MA, Petersen FB, Storb R, Fuchs EJ, Maloney DG: Comparison of outcomes of HLA-matched related, unrelated, or HLAhaploidentical related hematopoietic cell transplantation following nonmyeloablative conditioning for relapsed or refractory Hodgkin lymphoma. Biol Blood Marrow Transplant 2008;14:1279-1287.

33 Brunstein CG, Fuchs EJ, Carter SL, Karanes C, Costa LJ, Wu J, Devine SM, Wingard JR, Aljitawi OS, Cutler CS, Jagasia MH, Ballen KK, Eapen M, O’Donnell PV; Blood and Marrow Transplant Clinical Trials Network: Alternative donor transplantation after reduced intensity conditioning: results of parallel phase 2 trials using partially HLA-mismatched related bone marrow or unrelated double umbilical cord blood grafts. Blood 2011;118:282-288.

34 Bayraktar UD, Bashir Q, Qazilbash M, Champlin RE, Ciurea SO: Fifty years of melphalan use in hematopoietic stem cell transplantation. Biol Blood Marrow Transplant 2013;19: 344-356. 
35 Ciurea SO, Saliba R, Rondon G, Pesoa S, Cano P, Fernandez-Vina M, Qureshi S, Worth LL, McMannis J, Kebriaei P, Jones RB, Korbling M, Qazilbash M, Shpall EJ, Giralt S, de Lima M, Champlin RE, Gajewski J: Reduced-intensity conditioning using fludarabine, melphalan and thiotepa for adult patients undergoing haploidentical SCT. Bone Marrow Transplant 2010;45:429-436.

36 Di Stasi A, Milton DR, Poon LM, Hamdi A, Rondon G, Chen J, Pingali SR, Konopleva M, Kongtim P, Alousi A, Qazilbash MH, Ahmed S, Bashir Q, Al-atrash G, Oran B, Hosing CM, Kebriaei P, Popat U, Shpall EJ, Lee DA, de Lima M, Rezvani K, Khouri IF, Champlin RE, Ciurea SO: Similar transplantation outcomes for acute myeloid leukemia and myelodysplastic syndrome patients with haploidentical versus 10/10 human leukocyte antigen-matched unrelated and related donors. Biol Blood Marrow Transplant 2014;20:1975-1981.

37 Brammer JE, Stentz A, Gajewski J, Curtin P, Hayes-Lattin B, Kovacsovics T, Leis JF, Mey- ers G, Nemecek E, Subbiah N, Frires R, Palmbach G, Avraham GP, Slater S, Maziarz RT: Nonmyeloablative allogeneic hematopoietic stem cell transplant for the treatment of patients with hematologic malignancies using busulfan, fludarabine, and total body irradiation conditioning is effective in an elderly and infirm population. Biol Blood Marrow Transplant 2015;21:89-96.

38 Wang HT, Chang YJ, Xu LP, Liu DH, Wang Y, Liu KY, Hung XJ: EBMT risk score can predict the outcome of leukaemia after unmanipulated haploidentical blood and marrow transplantation. Bone Marrow Transplant 2014;49:927-933.

39 Handgretinger R, Lang P, Schumm M, Pfeiffer M, Gottschling S, Demirdelen B, Bader P, Kuci S, Klingebiel T, Niethammer D: Immunological aspects of haploidentical stem cell transplantation in children. Ann NY Acad Sci 2001;938:340-357.

40 Ross D, Jones M, Komanduri K, Levy RB: Antigen and lymphopenia-driven donor $\mathrm{T}$ cells are differentially diminished by post-transplantation administration of cyclophosphamide after hematopoietic cell transplantation. Biol Blood Marrow Transplant 2013;19:1430-1438.

41 Ganguly S, Ross DB, Panoskaltsis-Mortari A, Kanakry CG, Blazar BR, Levy RB, Luznik L: Donor CD4+ Foxp3+ regulatory $\mathrm{T}$ cells are necessary for posttransplantation cyclophosphamide-mediated protection against GVHD in mice. Blood 2014;124:2131-2141.

42 Powles RL, Morgenstern GR, Kay HE, McElwain TJ, Clink HM, Dady PJ, Barrett A, Jameson B, Depledge MH, Watson JG, Sloane J, Leigh M, Lumley H, Hedley D, Lawler SD, Filshie J, Robinson B: Mismatched family donors for bone-marrow transplantation as treatment for acute leukaemia. Lancet 1983;1: 612-615.

43 Mulanovich VE, Jiang Y, de Lima M, Shpall EJ, Champlin RE, Ciurea SO: Infectious complications in cord blood and T-cell depleted haploidentical stem cell transplantation. Am J Blood Res 2011;1:98-105. 